\title{
Perilaku Seks Pranikah Remaja
}

\author{
Premarital Sexual Inisiation of Adolescence
}

Komang Yuni Rahyani* Adi Utarini** Siswanto Agus Wilopo** Mohammad Hakimi**

\author{
*Jurusan Kebidanan Politeknik Kesehatan Kementerian Kesehatan Denpasar Bali, **Ikatan Kesehatan \\ Masyarakat Universitas Gadjah Mada
}

\begin{abstract}
Abstrak
Hubungan seksual sebelum nikah pada remaja merupakan masalah yang serius, berhubungan dengan peningkatan penularan penyakit menular seksual, mempunyai pasangan lebih dari satu, dan kehamilan dini. Suatu kerangka kerja model perilaku terintegrasi (Integrated Behavioral Model, IBM) digunakan untuk menilai berbagai faktor prediktor hubungan seksual prematur pada remaja. Tujuan penelitian ini adalah mengeksplorasi inisiasi hubungan seksual sebelum nikah pada remaja level 10 dan 11 berdasarkan kerangka kerja IBM, meliputi komunikasi tentang seks kelompok peers, orang tua, paparan perilaku pornografi, kepercayaan normatif, agen personal, dan keinginan hubungan seksual. Metode yang digunakan adalah menyertakan 626 responden dalam survei awal. Responden adalah siswa sekolah menengah atas level 10 - 11 di kota Denpasar. Data dikumpulkan dengan kuesioner laporan sendiri khususnya prediktor inisiasi hubungan seksual sebelum menikah. Penelitian ini menemukan bahwa pajanan pornografi, perilaku langsung dan tidak langsung berhubungan secara signifikan dengan inisiasi hubungan seksual sebelum nikah (nilai $p<0,05$ ). Remaja laki-laki tampaknya melakukan lebih banyak aktivitas seksual daripada remaja perempuan. Penelitian ini berimplikasi terhadap pemahaman perilaku langsung dan pajanan pornografi mungkin digunakan dalam meningkatkan program kesehatan dan kesehatan remaja.

Kata kunci: Hubungan seksual sebelum nikah, penyakit menular seksual, remaja
\end{abstract}

\section{Abstract}

Premarital sexual inisiation on adolescence is a serious problem, associated with increased transmition sexually transmitted disease/STD, had having more partners, and early pregnancy. An Integrated Behavioral Model (IBM) framework used to assess predictors of premarital sexual on adolescents. The purpose of this research is to explore predictors of premarital sexual inisiation in adolescents grade 10 and 11 based on IBM framework, includes: communication about sex with peers, parents, pornography exposure, attitude, normative belief, personal agency, and intention to have sex. Method that used is 626 respondent included in earlier survey, and respondent were students of senior high school grade 10 - 11 in Denpasar City. Data collected with self reported questionaire particularly predictor of premarital sexual initiation. The result found that pornography exposure, indirectly attitude, and directly attitude were significantly associated with premarital sexual initiation $(p<0,05)$. Male adolescents engage in more sexual activity like premarital sexual inisiation than female adolescents. This study has implications for understanding how directly attitude and pornography exposure may be used in intervention to promoting adolescents health program and adolescents ressiliency.

Keywords: Premarital sexual, sexually transmitted disease, adolescence

\section{Pendahuluan}

Perilaku seksual remaja, terutama perilaku seks pranikah, masih mendominasi perdebatan dari sisi moral, psikologis, dan fisik. Hubungan seks pranikah pada remaja adalah masalah serius karena berkaitan dengan rendahnya penggunaan kontrasepsi dan remaja cenderung memiliki lebih banyak pasangan seksual jika mulai berhubungan seks pranikah pada usia yang lebih dini. ${ }^{1,2}$ Menurut Glasier et al., ${ }^{3}$ seks yang tidak aman merupakan faktor risiko terpenting kedua bagi timbulnya kecacatan dan kematian di negara-negara miskin, serta faktor risiko terpenting ke-9 di negara-negara maju. Hubungan seks pranikah pada remaja mengalami peningkatan selama abad ke-20. Usia remaja mulai berhubungan seks pranikah bervariasi di tiap-tiap negara, berkisar dari $12-17,5$

Alamat Korespondensi: Komang Yuni, Jurusan Kebidanan Politeknik Kesehatan Kementerian Kesehatan Denpasar, Jl. Raya Puputan No. 11 A Renon Denpasar Bali, Hp.08123960632, e-mail: yunirahyani@yahoo.co.id 
tahun dan rata-rata dimulai sejak usia 15 tahun.1,2,4,5

Studi sebelumnya di Indonesia tentang perilaku seks pranikah remaja, memperoleh hasil sekitar 25\% - 51\% remaja telah berhubungan seks pranikah. ${ }^{6}$ Hasil Survei Kesehatan Reproduksi Remaja Indonesia (SKRRI) tahun 2007 menunjukkan sebesar 6,4\% remaja laki-laki dan $1,3 \%$ remaja perempuan telah melakukan hubungan seks pranikah. Studi di Bali memperoleh hasil remaja laki-laki di sekolah menengah atas (SMA) dan di sekolah menengah pertama (SMP) lebih banyak yang berhubungan seks pranikah $(40,3 \%$ dan $29,4 \%)$ dibandingkan dengan remaja perempuan $(3,6 \%$ dan $12,5 \%)$. Remaja laki-laki di Bali lebih permisif terhadap perilaku seks pranikah dibandingkan dengan remaja perempuan dan sekitar $5 \%$ remaja telah berhubungan seks pranikah. ${ }^{7}$

Isu yang masih diperdebatkan sampai saat ini mencakup motivasi utama remaja untuk melakukan inisiasi seks pranikah pada usia yang lebih dini selain kaitan antara sumber-sumber informasi seksual dan perilaku seksual remaja yang terbatas. ${ }^{8,9}$ Hasil penelitian Utomo dan McDonald, ${ }^{6}$ menunjukkan perilaku seks pranikah disebabkan oleh rangsangan secara terus-menerus melalui materi-materi seksual di media cetak, internet, serta melalui teman sebaya (peer). Berdasarkan Theory of Planned Behavior, Social Learning Theory, Diffusion of Innovations Theory, dan Ideation Model, teman sebaya berperan penting sebagai determinan utama dari perilaku.

Menurut Busse et al, ${ }^{10}$ remaja yang berkomunikasi dengan teman tentang seks cenderung meningkatkan kejadian inisiasi seks pranikah di antara remaja berusia 14 - 16 tahun di Philadelphia, sehingga perlu diketahui pengaruh komunikasi tentang seks dengan teman sebaya/akrab terhadap inisiasi hubungan seks pranikah remaja di Bali melalui elemen sikap, tekanan normatif, personal agency, serta niat. Artikel ini bertujuan menjabarkan hasil survei awal perilaku seks pranikah remaja yang duduk di bangku SMA tingkat 10 dan 11 di Bali berdasarkan prediktor-prediktor dari kerangka Integrated Behavioral Model. Menurut Cha et al., ${ }^{11}$ kerangka teori Integrated Behavioral Model sampai saat ini lebih banyak digunakan di negara-negara Barat, padahal teori Integrated Behavioral Model bisa digunakan di berbagai tempat atau dengan karakteristik yang berbeda. ${ }^{12,13}$

Fishbein, ${ }^{12,13}$ mengemukakan bahwa teori Integrated Behavioral Model adalah satu sintesis dari Theory Reasoned Action, Social Cognitive Theory, The Health Belief Model, dan Theory of Planned Behavior. Teori ini bermanfaat untuk menggali berbagai prediktor yang berpengaruh terhadap perilaku tertentu termasuk perilaku seks pranikah di antara remaja.

\section{Metode}

Rancangan studi yang digunakan adalah studi cross sectional, dan studi ini merupakan tahap awal dari studi longitu- dinal yang dilakukan selama 18 bulan sebanyak 3 tahap pengamatan, sejak Oktober 2011 hingga April 2013. Outcome yang akan diamati adalah perilaku inisiasi hubungan seks pranikah. Survei awal dilakukan sejak Oktober 2011 hingga Januari 2012. Survei ini adalah survei berbasis sekolah.

Responden yang dilibatkan adalah siswa tingkat 10 dan 11 pada dua sekolah menengah atas (SMA), yaitu SMA negeri dan swasta. Sejumlah 1.100 lembar informed consent telah disebarkan kepada siswa dan orang tua siswa. Peneliti telah memberikan penjelasan kepada pihak sekolah, wali kelas, guru bimbingan dan konseling, dan siswa tentang tujuan, manfaat, dan jaminan kerahasiaan responden sebelum pengumpulan data dilakukan. Informed consent yang dikembalikan dan telah ditandatangani oleh orang tua dan siswa sebanyak 741 lembar, yaitu 439 lembar $(79,82 \%)$ dari SMA negeri, dan 306 lembar $(68 \%)$ dari SMA swasta. Jumlah responden yang bersedia dilibatkan dalam penelitian sebanyak 626 orang terdiri dari 377 (93,32\%) siswa SMA negeri dan $249(92,22 \%)$ siswa SMA swasta.

Tahap awal survei dimulai dengan tahap persiapan, yaitu mengurus ethical clearance dari tim etik Fakultas Kedokteran Universitas Gadjah Mada (FK UGM), menyelesaikan izin penelitian, dan menguji coba instrumen penelitian. Uji coba instrumen dilakukan pada 2 SMA negeri di Denpasar dan menghasilkan korelasi item-item pertanyaan sudah valid dengan rentang dari 0,4-0,9 (data tidak ditampilkan).

Teknik pengumpulan data menggunakan self-reported questionaire digunakan untuk menggali data riwayat hubungan seks pranikah dan elemen Integrated Behavioral Model. Pelaksanaan uji coba instrumen berlangsung sejak Juli hingga Agustus 2011. Survei awal dilaksanakan dari Oktober 2011 hingga Januari 2012. Setelah pengumpulan data survei awal selesai dilaksanakan, penelitian dilanjutkan dengan menganalisis data penelitian, mencakup $d a-$ ta entry, cleaning data, dan analisis.

Variabel terikat atau outcome studi ini adalah inisiasi perilaku hubungan seks pranikah remaja tingkat 10 dan 11 di Kota Denpasar. Data perilaku hubungan seks pranikah diperoleh melalui jawaban pada self-reported status berdasarkan 5 pertanyaan, mencakup riwayat perilaku pacar atau pasangan memaksa berhubungan seksual atau tidak dan riwayat hubungan seks pranikah yang dilakukan dalam waktu 12 bulan terakhir. Variabel bebas diperoleh melalui kuesioner berisi pertanyaan tentang riwayat komunikasi tentang seks dan atau alat kontrasepsi dengan peer dalam 6 bulan terakhir. Jika responden menjawab pernah diberi skor 1 dan jika tidak pernah diberi skor 0 . Variabel antara mencakup sikap, tekanan normatif, personal agency, dan niat. Pengukuran sikap secara langsung menggunakan skala perbedaan semantik, skor rentang 1 7. Pengukuran sikap secara langsung menggunakan skala dari sangat setuju sampai sangat tidak setuju, skor dari -3 
Tabel 1. Karakteristik Responden di Bali

\begin{tabular}{|c|c|c|c|c|c|c|c|c|}
\hline \multirow{3}{*}{ Variabel } & \multirow{3}{*}{ Kategori } & \multicolumn{4}{|c|}{ Survei di Bali $(n=626)$} & \multirow{3}{*}{ OR } & \multirow{3}{*}{$95 \% \mathrm{CI}$} & \multirow{3}{*}{ Nilai $p$} \\
\hline & & \multicolumn{2}{|c|}{ Perempuan } & \multicolumn{2}{|c|}{ Laki-Laki } & & & \\
\hline & & n & $\%$ & $\mathbf{n}$ & $\%$ & & & \\
\hline \multirow[t]{2}{*}{ Tempat Tinggal } & Urban/kota & 293 & 53,1 & 259 & 46,9 & 0,9 & $0,5-1,5$ & - \\
\hline & Desa/pinggiran & 37 & 50 & 37 & 50 & & & \\
\hline \multirow{5}{*}{$\begin{array}{l}\text { Komunikasi tentang } \\
\text { seks dengan peer } \\
\text { Orang tua diajak } \\
\text { berdiskusi }\end{array}$} & Tidak pernah & 166 & 47 & 187 & 53 & 0,6 & $0,4-0,8$ & $<0,005$ \\
\hline & Pernah & 164 & 60,3 & 108 & 39,7 & & & \\
\hline & Ibu & 118 & 89,4 & 45 & 50 & & & \\
\hline & Ayah & 7 & 5,3 & 40 & 44,4 & 15 & $6-42$ & $<0,001$ \\
\hline & Tidak ada & 7 & 5,3 & 5 & 5,6 & 1,9 & $0,4-7,2$ & - \\
\hline \multirow{7}{*}{$\begin{array}{l}\text { Sumber Informasi } \\
\text { tentang seks/kontrasepsi }\end{array}$} & Televisi & 77 & 63,1 & 45 & 36,9 & 0,6 & $0,4-0,9$ & $<0,05$ \\
\hline & Internet & 93 & 39,6 & 142 & 60,4 & 2,3 & $1,7-, 3$ & $<0,005$ \\
\hline & Majalah & 36 & 60 & 24 & 40 & 0,7 & $0,4-1,3$ & - \\
\hline & Video games & 2 & 25 & 6 & 75 & 3,4 & $0,6-34,6$ & - \\
\hline & Koran & 19 & 63,3 & 11 & 36,7 & 0,6 & $0,3-1,4$ & - \\
\hline & Sekolah & 82 & 71,3 & 33 & 28,7 & 0,4 & $0,2-0,6$ & $<0,005$ \\
\hline & Lain-lain & 15 & 44,1 & 19 & 55,9 & 1,4 & $0,7-3,1$ & - \\
\hline \multirow[t]{6}{*}{ Perilaku berisiko sampel } & Merokok & 12 & 12,8 & 82 & 87,2 & 10,1 & $5,3-20,9$ & $<0,005$ \\
\hline & Anggota geng & 45 & 33,6 & 89 & 66,4 & 2,7 & $1,8-4,2$ & $<0,005$ \\
\hline & Minum minuman keras & 22 & 18,6 & 96 & 81,4 & 6,7 & $4,1-11,5$ & $<0,005$ \\
\hline & Menggunakan narkoba/NAPZA & 2 & 50 & 2 & 50 & 1,1 & $0,1-15,4$ & - \\
\hline & Tidak tinggal dengan orang tua & 35 & 58,3 & 25 & 41,7 & 0,8 & $0,4-1,4$ & - \\
\hline & Pernah hubungan seks pranikah & 6 & 1,8 & 23 & 7,8 & 4,5 & $1,8-13,8$ & $<0,005$ \\
\hline
\end{tabular}

sampai +3. Pengukuran sikap dibedakan menjadi sikap yang mendukung dan menolak seks pranikah.

Data mengenai tekanan normatif diperoleh berdasarkan pernyataan responden mengenai hubungan seks pranikah dirasakan penting/dikehendaki atau tidak oleh lingkungan terdekat terutama dari teman sebaya, orang tua, dan pacar. Pengukuran dari rentang sangat tidak setuju sampai sangat setuju rentang dari -3 sampai +3 .

Personal agency untuk mengukur derajat keyakinan sampel menunjukkan perilaku inisiasi seks pranikah yang diawali oleh berbagai hambatan atau tantangan dari dalam diri maupun dari lingkungan. Pengukuran terentang dari "tentu saya dapat menolak" hingga "tentu saya tidak dapat menolak" dengan skor 1 sampai 7.

Niat adalah kehendak atau keinginan untuk melakukan hubungan seks pranikah dengan pacar/pasangan dalam waktu 6 bulan dari saat diberikan pertanyaan. Pengukuran niat direntang dari sangat tidak setuju hingga sangat setuju, skor dari -3 sampai +3. Variabel luar yang diamati adalah komunikasi dengan orangtua, terpapar media pornografi, dan lama waktu remaja sendiri di rumah.

Setelah pengumpulan data, dilanjutkan analisis data tahap 1. Hasil analisis deskriptif data survei awal mencakup perbedaan karakteristik responden laki-laki dan perempuan. Analisis logistik regresi digunakan untuk menguji besarnya pengaruh variabel bebas, variabel antara, dan variabel luar terhadap perilaku seks pranikah remaja.

\section{Hasil}

Berdasarkan 626 orang responden di dua SMA tingkat 10 dan 11 pada survei awal, diperoleh jumlah responden laki-laki sejumlah 296 orang $(47,3 \%)$ dan responden perempuan sebanyak 330 orang $(52,7 \%)$. Ratarata umur responden adalah 16,4 tahun, rentang usia dari 14,2 - 19,1 tahun. Tabel 1 menunjukkan bahwa sebagian besar responden tinggal di daerah perkotaan. Responden perempuan lebih banyak yang pernah berdiskusi tentang seks dengan peer dibandingkan dengan responden laki-laki dengan $\mathrm{OR}=0,6(95 \% \mathrm{CI}=0,4-0,8)$.

Sumber informasi tentang seks diperoleh sebagian besar melalui televisi, internet, bahkan sekolah. Responden laki-laki lebih banyak berperilaku berisiko seperti merokok, menjadi anggota geng, mengonsumsi minuman keras, serta pernah berhubungan seks pranikah (Tabel 1).

Pada Tabel 2 didapatkan hasil bahwa terdapat perbedaan yang signifikan pada elemen Integrated Behavioral Model dan karakteristik lain berdasarkan jenis kelamin. Responden laki-laki cenderung berperilaku berisiko karena lebih banyak bersikap mendukung seks pranikah, mengalami tekanan normatif lebih tinggi, personal agency yang rendah, serta niat yang tinggi untuk melakukan hubungan seks pranikah. Komunikasi yang tidak baik dengan orang tua lebih banyak dilaporkan oleh responden laki-laki (OR $=2,6$ dan $95 \% \mathrm{CI}=1,5-4,7)$. Namun, perempuan lebih banyak yang tinggal di rumah sendirian dalam jangka waktu lebih lama dibandingkan dengan responden laki-laki (167 orang $(61,4 \%), 105$ orang $(38,6 \%)$.

Berdasarkan analisis bivariat diperoleh bahwa tekanan normatif yang cukup tinggi tidak berhubungan dengan perilaku inisiasi seks pranikah pada responden dengan $\mathrm{OR}=2,9(95 \% \mathrm{CI}=0,7-26,4)$. Elemen Integrated Behavioral Model mencakup sikap tidak langsung, sikap 
Tabel 2. Deskripsi Variabel Antara dan Variabel Luar pada Responden

\begin{tabular}{|c|c|c|c|c|c|c|c|c|}
\hline \multirow{3}{*}{ Variabel } & \multirow{3}{*}{ Kategori } & \multicolumn{4}{|c|}{ Total responden $(n=626)$} & \multirow{3}{*}{ OR } & \multirow{3}{*}{$95 \% \mathrm{CI}$} & \multirow{3}{*}{ Nilai p } \\
\hline & & \multicolumn{2}{|c|}{ Perempuan } & \multicolumn{2}{|c|}{ Laki-laki } & & & \\
\hline & & n & $\%$ & $\mathbf{n}$ & $\%$ & & & \\
\hline \multirow[t]{2}{*}{ Sikap tidak langsung } & Positif & 260 & 69,2 & 116 & 30,8 & 5,8 & $4,0-8,3$ & $<0,0001$ \\
\hline & Negatif & 70 & 28,0 & 180 & 72,0 & & & \\
\hline \multirow[t]{2}{*}{ Sikap langsung } & Positif & 298 & 62,3 & 180 & 37,7 & 6,0 & $3,8-9,6$ & $<0,0001$ \\
\hline & Negatif & 32 & 21,6 & 116 & 78,4 & & & \\
\hline \multirow[t]{2}{*}{ Tekanan normatif } & Cukup & 213 & 51,6 & 200 & 48,4 & 3,6 & $1,9-6,6$ & $<0,0001$ \\
\hline & Tinggi & 36 & 37,9 & 59 & 62,1 & 2,1 & $1,3-3,3$ & $<0,001$ \\
\hline \multirow[t]{2}{*}{ Personal agensi } & Tinggi & 307 & 71,2 & 124 & 28,8 & 18,5 & $11,2-31,3$ & $<0,0001$ \\
\hline & Rendah & 23 & 11,8 & 172 & 88,2 & & & \\
\hline \multirow[t]{2}{*}{ Niat } & Rendah & 294 & 65,8 & 153 & 34,2 & 7,6 & $4,9-11,9$ & $<0,0001$ \\
\hline & Tinggi & 36 & 20,1 & 143 & 79,9 & & & \\
\hline \multirow{4}{*}{$\begin{array}{l}\text { Komunikasi tentang seks } \\
\text { dengan orang tua } \\
\text { Terpapar tayangan } \\
\text { pornografi }\end{array}$} & Kurang baik & 239 & 55,8 & 189 & 44,2 & 13,6 & $6,6-28,7$ & $<0,0001$ \\
\hline & Tidak baik & 21 & 19,6 & 86 & 80,4 & 2,6 & $1,5-4,7$ & $<0,001$ \\
\hline & Tidak & 267 & 70,1 & 114 & 29,9 & 6,8 & $4,6-9,9$ & $<0,0001$ \\
\hline & Ya & 63 & 25,7 & 182 & 74,3 & & & \\
\hline \multirow{2}{*}{$\begin{array}{l}\text { Lama sendirian } \\
\text { di rumah }\end{array}$} & Sebentar & 163 & 46,1 & 191 & 53,9 & 0,5 & $0,4-0,7$ & $<0,001$ \\
\hline & Lama & 167 & 61,4 & 105 & 38,6 & & & \\
\hline
\end{tabular}

Tabel 3. Uji Bivariat Variabel Antara dengan Perilaku Seks Pranikah Remaja

\begin{tabular}{llll}
\hline Variabel Antara & OR & 95\% CI & Nilai p \\
\hline Sikap tidak langsung & 10,3 & $3,5-41,2$ & $<0,0001$ \\
Sikap langsung & 11,7 & $4,7-33,1$ & $<0.0001$ \\
Tekanan normatif tinggi & 4,6 & $0,8-46,3$ & $<0,05$ \\
Tekanan normatif cukup & 2,9 & $0,7-26,4$ & $>0,05$ \\
Personal agensi & 9,5 & $3,7-28,8$ & $<0,0001$ \\
Niat & 10,8 & $4,2-33,0$ & $<0,0001$ \\
\hline
\end{tabular}

Tabel 4. Hasil Uji Multivariat antara Karakteristik Responden, Elemen IBM, dengan Periaku Seks Pranikah Remaja

\begin{tabular}{llll}
\hline Variabel & OR & $95 \%$ CI & Nilai p \\
\hline Sikap tidak langsung & 4,3 & $1,3-13,5$ & 0,01 \\
Sikap langsung & 4,3 & $1,7-11,1$ & 0,003 \\
Terpapar pornografi & 5,2 & $1,7-15,9$ & 0,004 \\
\hline $\mathrm{N}$ & & & \\
$2 \times$ log likelihood & 625 & \\
Pseudo R & $2 \times 88,4$ & \\
\hline
\end{tabular}

Keterangan : dari 626 responden, hanya 1 responden yang tidak melengkapi data, sehingga total data dianalisis sebanyak 625 responden

langsung, tekanan normatif yang tinggi, personal agency, dan niat berhubungan secara bermakna dengan perilaku inisiasi hubungan seks pranikah (Tabel 3).

Analisis multivariat menggunakan logistik regresi dengan metode stepwise dan analisis variat dilakukan secara bersamaan dengan memasukkan semua prediktor yang memenuhi persyaratan analisis (Tabel 4). Selanjutnya, software analisis data secara otomatis mengeluarkan variabel yang tidak signifikan. Prediktor terkuat dari perilaku inisiasi seks pranikah remaja di Bali adalah terpapar pornografi, selain sikap langsung dan sikap tidak langsung. Terpapar pornografi cenderung meningkatkan perilaku inisiasi seks pranikah sebesar 5,2 kali dibandingkan tidak terpapar pornografi $(95 \% \mathrm{CI}=1,7-15,9)$.

Hampir 15\% responden pada survei awal mengaku pernah dipaksa atau dirayu oleh pacar untuk melakukan hubungan seks pranikah (data tidak ditampilkan). Sebanyak 29 responden $(4,26 \%)$ mengaku sudah melakukan hubungan seks pranikah bersama pacar/pasangan dalam satu tahun terakhir $(1,44 \%$ remaja perempuan dan 3,19\% remaja laki-laki). Responden laki-laki lebih banyak yang mengaku pernah berhubungan seks pranikah dibandingkan responden perempuan.

Berdasarkan hasil survei awal di Bali diperoleh alasan utama responden laki-laki usia 14 - 16 tahun mulai berhubungan seks pranikah, yakni rasa ingin tahu $(27,6 \%)$ dan merasa khilaf $(10,3 \%)$. Sebaliknya, responden perempuan beralasan tidak tahu $(6,9 \%)$, selain merasa sayang, takut menolak kemauan pacar, suka sama suka $(3,4 \%)$. Pola yang sama terlihat, bahwa remaja laki-laki lebih banyak yang mengaku telah berhubungan seks pranikah dibandingkan dengan remaja perempuan (Gambar 1).

\section{Pembahasan}

Responden laki-laki lebih banyak terlibat dalam perilaku berisiko disebabkan oleh pengaruh-pengaruh psikososial, seperti kemampuan untuk berpikir logis yang terbatas, pengaturan emosi yang lemah, serta rentan terhadap pengaruh teman sebaya. ${ }^{14}$ Teori-teori pembelajaran sosial digunakan untuk menjelaskan standar ganda. Contohnya adalah remaja perempuan dihukum atau dicela jika melakukan hubungan seks pranikah dengan dianggap perempuan murahan atau diisolasi dari pergaulan. Ini berbeda pada laki-laki, dianggap dapat menambah popularitas atau dikagumi. ${ }^{15}$

Proses modernisasi telah mengubah nilai-nilai dan keyakinan, termasuk norma mengenai hubungan seks 


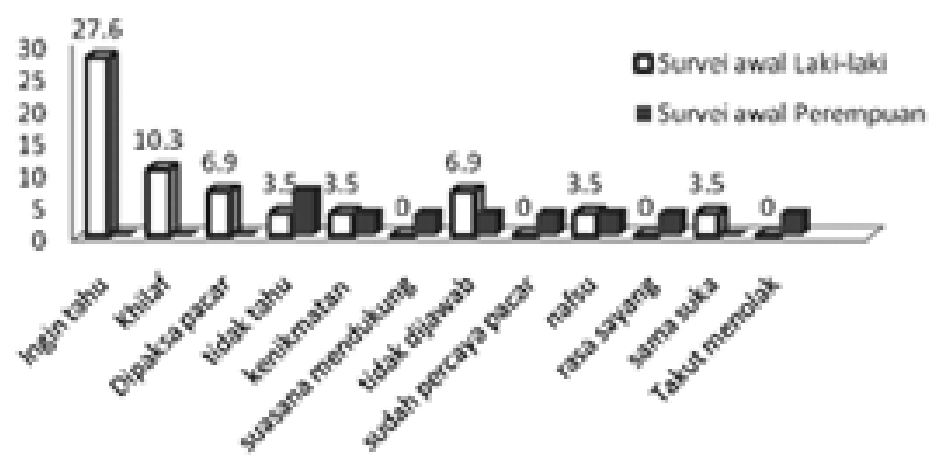

Gambar 1. Alasan Inisiasi Hubungan Seks Pranikah Responden

pranikah. Hubungan seks pranikah telah menyebar sangat cepat di antara remaja termasuk remaja di Bali. Menurut Dyson, 16 urbanisasi, penggunaan zat atau obat terlarang memicu perilaku berisiko terutama seks yang tidak aman sehingga meningkatkan penularan HIV/AIDS. Jumlah penderita HIV/AIDS tertinggi ke-5 di Indonesia adalah Bali (4.643/2.428) setelah DKI Jakarta, Papua, Jawa Timur, dan Jawa Barat. ${ }^{17}$ Nilai baru yang diterima masyarakat di Bali saat ini adalah hubungan seks pranikah diharapkan tidak menyebabkan kehamilan karena hamil di luar nikah menjadi aib tersendiri bagi remaja perempuan serta keluarganya. ${ }^{18}$

Remaja mempunyai persepsi yang overestimate terhadap perilaku teman sebaya, sehingga persepsi tentang teman sebaya merupakan determinan yang lebih kuat terhadap timbulnya perilaku berisiko. Remaja umumnya memilih teman sebaya berdasarkan perilaku mereka sendiri atau dikenal dengan "flocking phenomenon" ${ }^{19}$ Misalnya, remaja yang menjadi peminum alkohol akan memilih teman dengan perilaku yang sama.

Remaja laki-laki 4 kali lebih sering menonton film porno dibandingkan remaja perempuan. Umumnya, remaja secara teratur terpapar dengan materi-materi seksual di televisi, film, dan majalah di samping terpapar oleh tayangan video musik yang menggabungkan tayangan seks dan kekerasan. Berdasarkan studi sebelumnya diperoleh bahwa menonton pornografi merupakan faktor terkuat yang memengaruhi perilaku seks pranikah remaja laki-laki. ${ }^{20}$ Konten-konten seksual meningkatkan sikap yang mendukung seks pranikah, tetapi jalur antara terpapar dan hubungan seks pranikah belum dapat dipastikan.

Sikap yang mendukung atau setuju dengan perilaku seks pranikah lebih banyak ditunjukkan oleh responden laki-laki, sikap mengenai seks dibentuk oleh nilai-nilai keluarga dan budaya yang menolak seks pranikah. Sikap yang lebih permisif terhadap seks pranikah dapat dijadikan prediksi tingkat dari pengalaman inisiasi hubungan seksual prekoital dan koital pada remaja. Niat untuk berhubungan seks pranikah berhubungan dengan inisiasi hubungan seksual atau hubungan seksual dan terlibat di dalam sejumlah situasi-situasi progresif yang berisiko. 2,21,22 Niat secara langsung dipengaruhi oleh sikap, tekanan normatif, dan personal agency. Kemungkinan niat tidak berhubungan dengan perilaku seks pranikah remaja di Bali disebabkan karena pengaruh dari tekanan normatif serta personal agency kurang kuat. Berdasarkan teori sebelumnya, motivasi atau niat dapat ditampilkan jika tidak terdapat hambatan dari lingkungan, memiliki keterampilan yang memadai, sikap positif atau mendukung perilaku tertentu, tekanan norma sosial untuk bertindak, serta personal agency. ${ }^{12}$

Berbeda dengan hasil studi Huebner \& Laurie, ${ }^{23}$ yang menemukan asosiasi antara hubungan orang tua dan anak dengan perilaku seks remaja, hasil survei di Bali tidak menemukan asosiasi tersebut. Waktu atau saat komunikasi dilakukan memegang peranan cukup besar terutama bila dilakukan sebelum remaja mulai berhubungan seks pranikah. ${ }^{24}$ Kualitas komunikasi antara orang tua dengan remaja ditentukan oleh kemampuan orang tua untuk terbuka dan memberi respons yang tepat.

Remaja mulai melakukan hubungan seks pranikah disebabkan oleh berbagai faktor dan faktor yang berperan penting adalah situasi yang mendukung terjadinya hubungan seks pranikah tersebut. Menurut Paikoff, ${ }^{25}$ remaja melakukan hubungan seks pranikah akibat situasi atau kesempatan remaja bersama-sama di dalam ruangan yang pribadi dan kondisi ini disebut "situations of sexual possibility". Selain itu, remaja menyatakan bahwa seks dilakukan sesekali atau jarang, sehingga sulit untuk diprediksi. Oleh sebab itu, alasan remaja mulai melakukan hubungan seks pranikah lebih banyak tidak diketahui, selain karena hasrat atau dorongan seksual. Seks dianggap mencerminkan kebebasan, memelihara hubungan, kedekatan, keintiman, atau cinta. Rasa ingin tahu serta tekanan dari teman sebaya dan pasangan dapat meningkatkan kejadian hubungan seks pranikah.

Untuk mengurangi respons bias dari responden, diberikan penjelasan kepada tiap responden secara rinci tiap item kuesioner yang dimaksud. Dijelaskan pula jaminan ke- 
rahasiaan data yang diberikan oleh responden dan menggunakan anonimity pada kuesioner. Pengumpulan data dilakukan di ruangan yang disiapkan di sekolah yang memadai untuk menjaga privasi responden. Kelemahan dari studi ini adalah pada rancangan cross sectional karena merupakan tahap awal dari studi longitudinal yang dilakukan, selain jumlah sekolah yang dilibatkan cukup terbatas.

\section{Kesimpulan}

Keterpaparan media berupa tayangan pornografi dan sikap yang mendukung hubungan seks pranikah merupakan prediktor yang kuat bagi ditampilkannya perilaku hubungan seks pranikah remaja di Bali. Remaja laki-laki lebih banyak yang telah melakukan hubungan seks pranikah dibandingkan dengan remaja perempuan. Remaja perempuan juga lebih banyak pernah dipaksa oleh pacar/pasangan untuk melakukan hubungan seks pranikah.

\section{Saran}

Perlu dilakukan monitoring serta upaya-upaya meningkatkan resiliensi remaja menghindari tekanan atau pengaruh untuk mulai melakukan hubungan seks pranikah pada usia yang lebih dini. Orang tua harus lebih terbuka dalam berkomunikasi dengan remaja terkait seksualitas untuk membantu perkembangan remaja dan lebih kritis terhadap tayangan-tayangan pornografi. Studi selanjutnya hendaknya meneliti frekuensi komunikasi antara orang tua dengan remaja menyangkut seksualitas.

\section{Ucapan Terima Kasih}

Terima kasih sebesar-besarnya kepada para kepala sekolah, Drs. Made Wibawa, Drs. G.M. Murjana, dan Dra. I.A. Kendran.

\section{Daftar Pustaka}

1. American Academy of Pediatrics. Contraception and adolescents. Pediatrics. 1999; 104 (5): 1161-6.

2. Kinsman SB, Romer D, Furstenberg FF, Schwarz DF. Early sexual initiation: the role of peer norms. Pediatrics. 1998; 102 (5): 1185-92.

3. Glasier A, Gulmezoglu AM, Schmid GP, Moreno CG, Van Look PF. Sexual and reproductive health: a matter of life and death. Lancet. 2006; 368 (9547): 1595-607.

4. Guiella G, Madise NJ. HIV/AIDS and sexual-risk behaviors among adolescents: factors influencing the use of condoms in Burkina Faso. African Journal of Reproductive Health. 2007; 11(3): 182-96.

5. Raymundo CM. Sex files: all about the young and the currious. Manila: U.P. Population Institute; 2003.

6. Utomo ID, McDonald P. Adolescent reproductive health in Indonesia: contested values and policy inaction. Studies in Family Planning Journal. 2009; 40 (2): 133-46.

7. Faturochman. Sikap dan perilaku seksual remaja di Bali. Jurnal Psikologi. 1992; 1: $12-7$.

8. Buhi E, Goodson P. Predictors of adolescent sexual behavior and intention: a theory-guided systematic review. Journal of Adolescent Health. 2007; 40 (1): 4-21.
9. Hipwell AE, Keenan K, Loeber R, Battista D. Early predictors of sexually intimate behaviors in an urban sample of young girls. Developmental Psychology Journal. 2010; 46 (2): 366-78.

10. Busse P, Fishbein M, Bleakley A, Hennessy M. The role of communication with friends in sexual initiation. Communication Research. 2010; 37 (2): 239-55.

11. Cha ES, Kim KH, Patrick TE. Predictors of intention to practice safer sex among Korean college students. Archives of Sexual Behaviour Journal. 2008; 37(4): 641-51.

12. Fishbein M. The role of theory in HIV prevention. AIDS Care. 2000; 12 (3): 273-8.

13. Fishbein M, Cappella JN, Hornik R, Sayeed S, Yzer MC, Ahern RK. The role of theory in developing effective anti-drug public service announcements. In: Crano WD, Burgoon M, editors. Mass media and drug prevention: Classic and contemporary theories and research. Mahwah: Erlbaum; 2002. p. 89-117.

14. Steinberg L. Risk taking in adolescence: new perspectives from brain and behavioral science. Current Directions in Psychological Science. 2007; 16 (2): 55-9.

15. Sprecher S, Regan PC, McKinney K, Maxwell K, Wazienski R. Preferred level of sexual experience in a date or mate: the merger of two methodologies. The Journal of Sex Research. 1997; 34 (4): 327-37.

16. Dyson T. HIV/AIDS and urbanization. Population and Development Review. 2003; 29(3): 427-42.

17. Kementerian Kesehatan Republik Indonesia. Statistik kasus HIV/AIDS di Indonesia dilapor sampai Desember 2011. Jakarta: Kementerian Kesehatan Republik Indonesia Direktorat Jenderal Pengendalian Penyakit dan Penyehatan Lingkungan; 2011.

18. Duarsa DP. Remaja menantang bahaya! Fenomena kehamilan tak diinginkan di Kota Denpasar. 1st ed. Denpasar: Kajian Budaya Books dan Bali Mangsi Press; 2005.

19. Conger RD, Rueter MA. Siblings, parents, and peers: a longitudinal study of social influences in adolescent risk for alcohol use and abuse. Advanced Applied Developmental Psychology Journal. 1996; 10: 1-30.

20. Wong ML, Chan RK, Koh D, Tan HH, Lim FS, Emmanuel S, et al. Premarital sexual intercourse among adolescents in an Asian country: Multilevel ecological factors. Pediatrics. 2009; 124 (1): 44-52.

21. Gillmore MR, Archibald ME, Morrison DM, Wilsdon A, Wells EA, Hoppe MJ, et al. Teen sexual behavior: Applicability of the theory of reasoned action. Journal of Marriage and Family. 2002; 64 (4): 885-97.

22. Sieverding JA, Adler N, Witt S, Ellen J. The influence of parental monitoring on adolescent sexual initiation. Archives of Pediatrics and Adolescents Medicine Journal. 2005; 159 (8): 724-9.

23. Huebner AJ, Laurie WH. Examining the relationship between adolescent sexual risk-taking and perceptions of monitoring, communication, and parenting styles. Journal of Adolescent Health Education Resources. 2003; 33 (2): 71-8.

24. Clawson CL, Reese-Weber M. The amount and timing of parent-adolescent sexual communication as predictors of late adolescent sexual risk-taking behaviors. The Journal of Sex Research Volume 2003; 40 (3): 256-65.

25. Paikoff RL. Early heterosexual debut: situations of sexual possibility during the transition to adolescence. American Journal of Orthopsychiatry. 1995; 65 (3): 389-401. 